\title{
OPTIMIZATION OF A STEEL PENSTOCK WITH STIFFENER RINGS
}

Scientific paper / Znanstveni rad

\section{Stojan Kravanja}

University of Maribor, Faculty of Civil Engineering, Transportation Engineering and Architecture, Professor Corresponding author: stojan.kravanja@um.si

\begin{abstract}
The paper presents the optimization of a high-pressure steel penstock with stiffener rings, which is constructed in a bored tunnel for a pump storage hydroelectric plant. The optimization is performed using nonlinear programming (NLP) methods, and an NLP optimization model is developed. The mass of the steel structure is defined in the objective function to be minimized and structural (in)equality constraints are imposed. The latter comprise the dimensioning equations of a steel penstock, which is exposed to the internal and external water pressure cases. Only the main constraints are introduced in the paper. They include checking the circumferential stresses in the pipe owing to internal water pressure, as well as the critical pressures in the steel liner and stiffener rings when the pipe is exposed to the external water pressure. The numerical example at the end of the paper describes the optimization of the high-pressure steel penstock for the pumped hydropower plant Kozjak, which will be constructed in Slovenia near the city of Maribor.
\end{abstract}

Keywords: steel penstock; optimization; nonlinear programming; NLP

\section{OPTIMIZACIJA ČELIČNOG CJEVOVODA SA KRUŽNIM UKRUĆENJIMA}

Sažetak: U ovome je radu prikazana optimizacija čeličnog cjevovoda $s$ kružnim ukrućenjima koji je podvrgnut visokom pritsku vode, a izradit će se u izbušenom tunelu za reverzibilnu hidroelektranu. Optimizacija je izvedena nelinearnim programiranjem (NLP). Modeliran je NLP optimizacijski model konstrukcije cjevovoda. Masa čelične konstrukcije definirana je u ciljnoj funkciji koja se minimizira i podvrgnuta je uvjetnim jednadžbama i nejednadžbama. Ti uvjeti sadržavaju (ne)jednadžbe dimenzioniranja cjevovoda opterećenog unutrašnjim ivanjskim pritiskom vode. U radu su prikazane samo najvažnije uvjetne (ne)jednadžbe. One uključuju kontrolu tangencijalnih naprezanja u stjjenki cjevovoda zbog unutrašnjeg pritiska vode, kao i kontrolu kritičnog naprezanja u stjenki cjevovoda te ukrućenja zbog djelovanja vanjskog pritiska vode. Numerički primjer na kraju rada prikazuje optimizaciju čeličnog cjevovoda s ukrućenjima za reverzibilnu hidroelektranu Kozjak, koja će biti sagrađena u blizini Maribora u Sloveniji.

Ključne riječi: čelični cjevovod; optimizacija; nelinearno programiranje; NLP

Kravanja, S 


\section{INTRODUCTION}

The paper presents the optimization of a high-pressure steel penstock, constructed in a tunnel for a hydropower station. Much research has been performed recently in the field of penstock optimization. Tapia et al. [1] optimized micro-hydro power plants, including penstocks, using integer programming. Fathi-Moghadam et al. [2] introduced the optimization procedure of hydropower tunnels that uses a genetic algorithm. Bai et al. [3] presented the optimization of a stiffener penstock structure in a hydropower station using a simple genetic algorithm and a direct search method. Wu et al. [4] presented the optimization allocation of the reinforcement for a penstock using ABAQUS. Gu and Yan [5] reported the optimization of a penstock and expansion joint structure in a hydropower station. Haghighipour and Fathi-Moghadam [6] optimized hydropower conveyance systems, including penstocks, using a genetic algorithm. Anagnostopoulos and Papantonis [7] optimized the size of a penstock in a pumpedstorage power plant using evolutionary algorithms. Dong et al. [8] considered the stability problem of a hydroelectric station penstock under external pressure using an artificial neural network and simulated annealing. Li et al. [9] developed an optimal design model of a steel-lined reinforced concrete penstock based on the ANSYS finite element optimal technique and the zero-order method of the ANSYS optimization toolbox.

The optimization of a high-pressure penstock with a smooth circular steel liner (without stiffener rings) was already reported by Kravanja $[10,11]$. To increase the stability resistance of the smooth pipe with respect to the external water pressure, stiffener rings are built up onto the liner shell. Consequently, the thickness of the pipe shell and the mass of the pipe structure are reduced.

Contrary to references $[10,11]$, this paper reports the optimization of a steel penstock with siffener rings; the sytem is schematically shown in Figure. 1. The considered stiffener rings are made from welded rectangular hollow sections with two webs. Nonlinear programming (NLP) is used for optimizing the system. The NLP optimization model PIPEWSROPT is developed. The mass of the structure is defined in the objective function, which is subjected to structural constraints. The penstock should resist the internal water pressure, including the dynamic effect of a water hammer during filling, and the external water pressure, which is usually defined as a level of external groundwater. The structural constraints thus comprise the equations of the circumferential stresses in the pipe owing to the internal water pressure as well as the equations of the critical pressures in the steel liner and stiffener rings when the pipe is exposed to the external water pressure. The basic theory of the stability of cylindrical shells exposed to external pressure was introduced by Timoshenko [12] in 1940, while the theory of the stability of cylindrical penstocks with stiffener rings was introduced by E. Amstuz [13] in 1950 and [14] in 1953, and by Kollbrunner and Milosavljević [15] in 1956. The dimensioning constraints for the pipe with stiffener rings are defined in the optimization model PIPEWSROPT according to the C.E.C.T. recommendations for the design, manufacturing, and erection of steel penstocks of welded construction for hydroelectric installations [16], which include the stability theory of the pipes, presented in references [13-15].

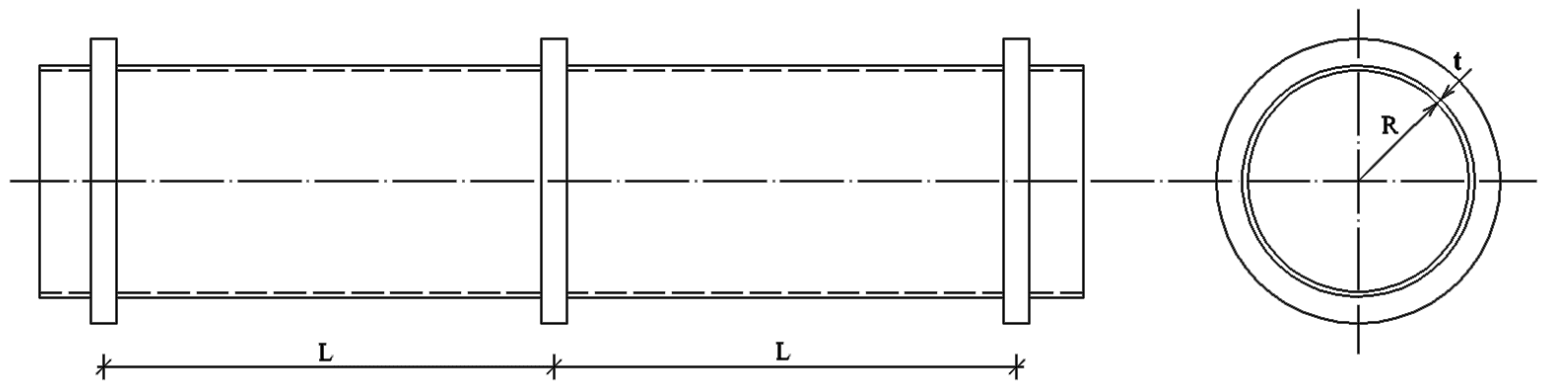

Figure 1 Steel penstock with stiffener rings (horizontal and vertical cross-sections)

The developed optimization model PIPEWSROPT was used for optimizing the high-pressure steel penstock at the hydropower plant Kozjak, which will be constructed in Slovenia near the city of Maribor. One of the variants of the optimized penstock is presented at the end of the paper. 


\section{OPTIMIZATION MODEL OF THE STEEL PENSTOCK WITH STIFFENER RINGS}

\subsection{NLP formulation}

The optimization problem of the steel penstock comprises nonlinear and linear functions involved in the objective and (in)equality constraints. All of the defined functions are continuous and differentiable. For this reason, NLP was selected for the optimization. In general, an NLP optimization problem takes the following form:

$\min z=f(x)$

subjected to:

$g_{k}(\mathbf{x}) \leq 0 \quad k \in K$

$\mathbf{x} \in X=\left\{\mathbf{x} \in R^{n}: \mathbf{x}^{\llcorner 0} \leq \mathbf{x} \leq \mathbf{x}^{\mathrm{UP}}\right\}$

where $\boldsymbol{x}$ is a vector of continuous variables, which are defined within their lower and upper bounds $x^{L 0}$ and $x^{U P}$. The function $z=f(x)$ is the objective function, subjected to the (in)equality constraints $g_{k}(x) \leq 0$. At least one of functions $f(x)$ or $g_{k}(\boldsymbol{x})$ must be a nonlinear function.

In the case of structural optimization, the continuous variables $x$ reflect the structure's dimensions, material grades, loads, and costs, to name a few. While the objective function usually defines the structure's mass or production costs, the (in)equality constraints represent different load, resistance, and deflection conditions.

\subsection{Optimization model PIPEWSROPT}

The optimization model PIPEWSROPT (PIPE With Stiffener Ring OPTimization) for the optimization of highpressure steel penstocks with rings was developed. The model was modeled in the GAMS (General Algebraic Modeling System) [17] environment. The model comprises input data (scalars), variables, and the mass objective function of the steel liner, which is subjected to the design and stability constraints. Only the main constraints are presented in the paper. They include checking the stability resistance conditions for the steel pipe, which is subjected to the external water pressure: checking the stability of the steel liner between two stiffener rings, checking the stability of stiffener rings, checking the critical pressure, and checking the elastic behavior of the material. The condition of the pipe loaded by the internal water pressure is also considered. Because the C.E.C.T. recommendations do not define allowances for deformations, only the constraints for stresses are included in the optimization model.

Input data (scalars) of the model include the inner radius of the penstock (an ideal pipe) $R$ [cm], the length of the penstock section $L_{\text {sect }}[\mathrm{cm}]$, the yield strength of the steel fy $\left[\mathrm{kN} / \mathrm{cm}^{2}\right]$, the corrosion allowance for the steel elements cor $[\mathrm{cm}]$, the internal water pressure $p_{\text {in }}\left[\mathrm{kN} / \mathrm{cm}^{2}\right]$, the external water pressure $p_{\text {ex }}\left[\mathrm{kN} / \mathrm{cm}^{2}\right]$, the safety factor relative to the internal water pressure $C_{i p}[-]$, the safety factor relative to the external water pressure $C_{e p}[-]$, the steel elasticity modulus $E\left[\mathrm{kN} / \mathrm{cm}^{2}\right]$, the Poisson factor $v[-]$, the coefficient defining the highest normal stress for which the structure still meets the requirements of Hooke's law $\varphi[-]$, the ratio $j_{R}$ between the interstitial clearance immediately after draining $j$ and the pipe inner radius $R: j_{R}=j / R[-]$, the ratio $\varepsilon$ between the maximal deviation $\eta$ (between a circle of radius $R$ and a pipe radial run-out) and the pipe radius $R: \varepsilon=\eta / R[-]$, the ratio $u_{e}$ between the maximal inward deviation $U$ and the theoretical pipe thickness e: $u_{e}=U / e[-]$, and the unit mass of steel $\rho\left[\mathrm{kg} / \mathrm{cm}^{3}\right]$.

The thickness of the pipe shell $t[\mathrm{~cm}]$, the theoretical thickness of the pipe shell $e[\mathrm{~cm}]$, the spacing between siffener rings $L[\mathrm{~cm}]$, the thickness of the stiffener ring web $t_{e}[\mathrm{~cm}]$, the theoretical thickness of the stiffener ring web $e_{0}[\mathrm{~cm}]$, the height of the stiffener ring $h_{0}[\mathrm{~cm}]$, the spacing between the ring webs $a_{0}[\mathrm{~cm}]$, the effective length of the penstock associated with the ring $L_{0}[\mathrm{~cm}]$, the cross-section area of the ring (including the effective penstock length) $A_{0}\left[\mathrm{~cm}^{2}\right]$, the maximal distance of the most upper fiber of the ring cross-section area from its gravity line $Y_{0}$ $[\mathrm{cm}]$, the radius of the gravity line of the ring cross-section $R_{0}[\mathrm{~cm}]$, the moment of inertia of the ring cross-section $I_{0}\left[\mathrm{~cm}^{4}\right]$, the stabilization factor $\alpha[-]$, the weakening factor of the smooth pipe owing to a general ovality (expressed by $\eta=0.01 R$ ) $\beta[-]$, the weakening coefficient of the smooth pipe owing a radial run-out (expressed by $U>0,1 e) \gamma$ $[-]$, the normal circumferential stress associated with the radius in the plate $\sigma_{N}\left[\mathrm{kN} / \mathrm{cm}^{2}\right]$, the normal circumferential stress associated with the radius in the ring $\sigma_{\mathrm{NO}}\left[\mathrm{kN} / \mathrm{cm}^{2}\right]$, the smallest normal circumferential stress $\sigma_{\mathrm{N} 0 \text {, min }}\left[\mathrm{kN} / \mathrm{cm}^{2}\right]$,

Kravanja, S 
the external critical pressure in the pipe with an ovality between two stiffener rings $p_{\mathrm{cr}}$,pipe $\left[\mathrm{kN} / \mathrm{cm}^{2}\right]$, the external critical pressure in the stiffener ring $p_{\mathrm{cr}}^{\mathrm{L}, \text { ring }}\left[\mathrm{kN} / \mathrm{cm}^{2}\right]$, the minimal external critical pressure $p_{\mathrm{cr}}{ }^{\mathrm{L}}\left[\mathrm{kN} / \mathrm{cm}^{2}\right]$ and the mass of the steel penstock (together with stiffener rings) mass [kg] are declared in the optimization model as variables.

The objective function defines the mass of a steel penstock section with stiffener rings (Eq. (1)). While the first term in the equation represents the mass of the pipe shell, the second and the third terms define the masses of stiffener rings, as is also shown in Figures 1 and 2.

$$
\begin{aligned}
\text { mass }= & \pi \cdot t \cdot(2 \cdot R+t) \cdot \rho \cdot L_{\text {sect }}+2 \pi \cdot h_{0} \cdot\left[2 \cdot(R+t)+h_{0}\right] \cdot e_{0} \cdot \rho \cdot L_{\text {sect }} / L+ \\
& \pi \cdot t \cdot\left[2 \cdot\left(R+t+h_{0}\right)+t\right] \cdot\left(a_{0}+2 \cdot e_{0}\right) \cdot \rho \cdot L_{\text {sect }} / L
\end{aligned}
$$

The penstock must resist the external water pressure $p_{\text {ex. }}$ The constraint Eq. (2) for checking the stability of the steel liner between two stiffener rings includes the calculation of the external critical pressure $p_{\mathrm{cr}} \mathrm{L}$,pipe in the pipe with an ovality according to the C.E.C.T. recommendations [16].

$$
p_{c r}^{L, p i p e}=\alpha \cdot \beta \cdot p_{c r}^{-i}
$$

Here, the external critical pressure of an ideal pipe without stiffeners $p_{c r}^{\mathrm{j}}$ is defined by Eq. (3):

$$
p_{c r}^{-i}=\frac{E^{*}}{4}\left(\frac{e}{R+e}\right)^{3}
$$

where

$$
E^{*}=E /\left(1-v^{2}\right)
$$

The weakening factor of the smooth pipe owing to a general ovality $\beta$ is determined by Eq. (5) for the maximal pipe deviation $\eta=0,01 \mathrm{R}$, according to Kollbrunner and Milosavjjević [15]:

$$
\beta=\frac{\gamma_{K M}}{2} \pm \sqrt{\frac{\gamma_{K M}^{2}}{4}-v}
$$

$\beta \leq 1,0$

where the terms in Eq. (5) are defined by Eqns. (7)-(11):

$$
\begin{aligned}
& \gamma_{K M}=v+6 \frac{\varepsilon}{\varphi_{K M}}+1 \\
& v=f_{y} \cdot \varphi_{K M} / p_{0} \\
& \varphi_{K M}=e / R \\
& p_{0}=\frac{E}{4\left(1-v^{2}\right)} \cdot \varphi_{K M}^{3} \\
& \varepsilon=\eta / R=0.01
\end{aligned}
$$

The stabilization factor $\alpha$ is given by Eq. (12). It is assumed that the penstock can be considered rigidly encased and the rings are capable of resisting a twist. In this case, the spacing between the rings $L$ can be replaced with a fictitious (reduced) distance between the rings $L_{f}(E q$. (14)):

$\alpha=\frac{3.34}{\psi \sqrt{\varphi_{K M}}}+\frac{4}{9}\left(\frac{\pi^{2}}{\psi^{2}}-\frac{1}{2}\right)$

Kravanja, S 
where

$\psi=L_{f} / R$

$L_{f}=0.8 \cdot\left(L-a_{0}\right)$

The design maximal external water pressure on the penstock $\left(C_{\mathrm{ep}} \cdot p_{\mathrm{ex}}\right)$ must be lower than the external critical pressure in the pipe and in the ring $p_{\mathrm{cr}} \mathrm{L}$, as given by Eq. (15):

$C_{e p} \cdot p_{e x} \leq p_{c r}^{L}$

The stability of the stiffener rings is determined by Eqns. (16) and (17), where $\sigma_{\mathrm{N} 0}$ represents the normal circumferential stress associated with the radius of the ring and $p_{\mathrm{cr}}$,ring is the external critical pressure in the stiffener rings.

$$
\begin{aligned}
& 0.58 \cdot \frac{Y_{0}}{R} \cdot\left(\sigma_{N 0}+E \frac{j}{R_{0}}\right) \cdot\left(1+\frac{\sigma_{N 0}}{E} \cdot \frac{L}{L_{0}} \cdot \frac{A_{0} \cdot R_{0}^{2}}{I_{0}+\frac{L-L_{0}}{12} \cdot e^{3}}\right)^{3 / 2} \leq\left(f_{y}-\sigma_{N 0}\right) \cdot\left(1-0.23 \cdot \frac{R_{0}}{Y_{0}} \cdot \frac{f_{y}-\sigma_{N 0}}{E}\right) \\
& p_{c r}^{L, \text { ring }}=\sigma_{N 0} \cdot \frac{A_{0}}{L_{0} \cdot R_{0}} \cdot\left(1+0.175 \cdot \frac{R_{0}}{Y_{0}} \cdot \frac{f_{y}-\sigma_{N 0}}{E}\right)^{-1}
\end{aligned}
$$

The cross-section characteristics of the stiffener rings are defined by Eqns. (18)-(26), as follows. The stiffener rings considered have a welded rectangular hollow cross-section with two webs, where the effective length of the penstock associated with the ring, $L_{0}$, defines its lower flange, as shown in Figure 2.

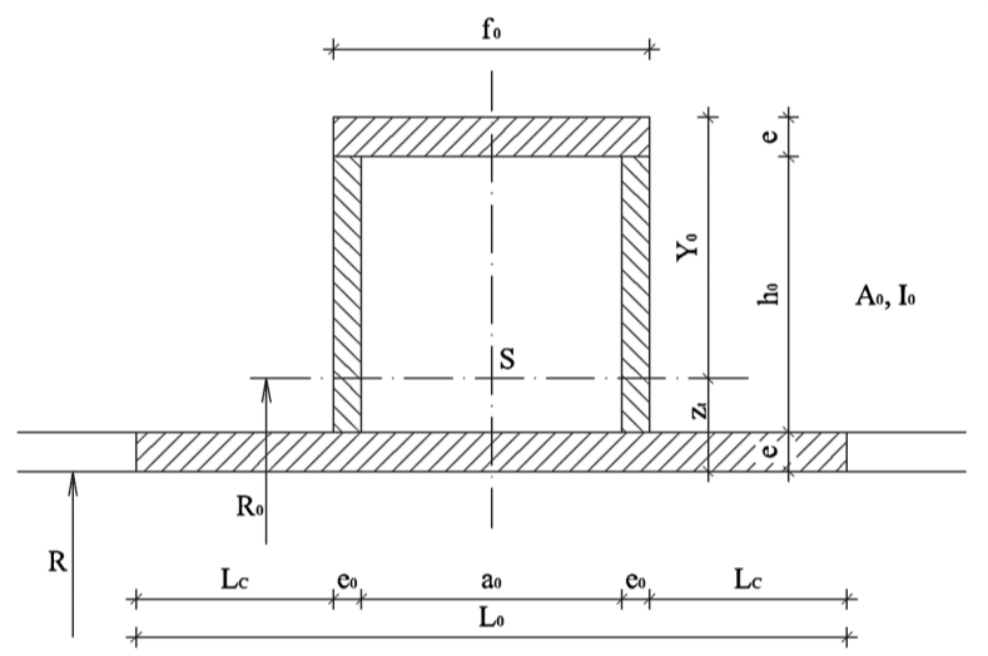

$e_{0}=t_{e}-c o r$

Figure 2 Cross-section of the stiffener ring

$L_{c}=0.78 \sqrt{R \cdot e}$

$L_{0}=2\left(L_{c}+e_{0}\right)+a_{0}$

$f_{0}=a_{0}+2 e_{0}$

$A_{0}=L_{0} \cdot e+2 h_{0} \cdot e_{0}+f_{0} \cdot e$

$z_{t}=\left[L_{0} \cdot e \cdot \frac{e}{2}+2 h_{0} \cdot e_{0} \cdot\left(e+\frac{h_{0}}{2}\right)+f_{0} \cdot e \cdot\left(\frac{3 e}{2}+h_{0}\right)\right] / A_{0}$

\section{Kravanja, S}


$R_{0}=R+z_{t}$

$Y_{0}=2 e+h_{0}-z_{t}$

$I_{0}=\frac{L_{0} \cdot e^{3}}{12}+L_{0} \cdot e \cdot\left(\frac{e}{2}-z_{t}\right)^{2}+2 \cdot \frac{e_{0} \cdot h_{0}^{3}}{12}+2 \cdot h_{0} \cdot e_{0} \cdot\left(e+\frac{h_{0}}{2}-z_{t}\right)^{2}+\frac{f_{0} \cdot e^{3}}{12}+f_{0} \cdot e \cdot\left(\frac{3 e}{2}+h_{0}-z_{t}\right)^{2}$

The normal circumferential stress associated with the radius of the ring, $\sigma_{\mathrm{N} 0}$, must be smaller than the highest elastic stress of steel (steel still meets the requirements of Hooke's law), as given in Eq. (27).

$\sigma_{N 0} \leq \varphi \cdot f_{y}$

The critical external pressure $p_{\mathrm{cr}}{ }^{L}$, for which the penstock together with the stiffener rings shows the stability resistance, has to be taken as the smaller of the critical pressures $p_{\mathrm{cr}}{ }^{\text {,pipe }}$ and $p_{\mathrm{cr}}{ }^{L}$,ring (Eq. (28)).

$p_{c r}^{L}=\min \left\{\begin{array}{l}p_{c r}^{L, \text { pipe }} \\ p_{c r}^{L, \text { ring }}\end{array}\right\}$

The elastic behavior of the material is checked by Eqns. (29)-(31). The condition of the normal circumferential stress associated with the radius of the plate, $\sigma_{N}$, must be satisfied by Eq. (29); where $\sigma_{N 0 \text {, min }}$ is determined by Eq. (17) for the defined $p_{\mathrm{cr}}{ }^{2}$ (Eq. (28)), $\sigma_{\mathrm{N}, \text { min }} \leq \sigma_{\mathrm{NO}}$.

$\sigma_{N} \leq \varphi \cdot \gamma \cdot f_{y}$

where

$$
\begin{aligned}
& \sigma_{N}=\frac{p_{c r}^{L} \cdot L \cdot R-\sigma_{N 0, \min } \cdot A_{0}}{\left(L-L_{0}\right) \cdot e} \\
& \gamma=1-3 \cdot p_{c r}^{L} \cdot \frac{R}{f_{y} \cdot e}\left(\frac{U}{e}-0.1\right)
\end{aligned}
$$

When the penstock is exposed to the internal water pressure, the pipe's longitudinal contraction is prevented by the neighboring concrete and rock. Consequenty, the circumferential tensile stresses $\sigma_{\theta}$ and the longitudinal tensile stresses $\sigma_{\mathrm{x}}$ (because of the prevented contraction) occur in the pipe. Because of this two-dimensional stress state, the stresses in the pipe are reduced by $11 \%$. The reduced design stress in the pipe $\left(C_{\mathrm{ip}} \cdot \sigma_{\mathrm{eq}}\right)$ is constrained by Eq. (32), where the reduced stress in the pipe $\left(\sigma_{\text {eq }}\right)$, the Poisson factor $v$ for steel, and the circumferential stress $\sigma_{\theta}$ in the pipe owing to the internal water pressure $p_{\text {in }}$ are determined by Eqns. (33)-(35):

$C_{i p} \cdot \sigma_{e q} \leq f_{y}$

where

$$
\begin{aligned}
& \sigma_{e q}=\sqrt{\sigma_{x}^{2}+\sigma_{\theta}^{2}-\sigma_{x} \cdot \sigma_{\theta}}=\sqrt{\left(v \cdot \sigma_{\theta}\right)^{2}+\sigma_{\theta}^{2}-\left(v \cdot \sigma_{\theta}\right) \cdot \sigma_{\theta}}=0.89 \sigma_{\theta} \\
& v=0.3 \\
& \sigma_{\theta}=p_{\text {in }} \cdot R / e
\end{aligned}
$$




\section{OPTIMIZATION OF THE HIGH-PRESSURE PENSTOCK KOZJAK}

The following numerical example demonstrates the NLP optimization of the high-pressure steel penstock for the hydroelectric power plant Kozjak, which is planned to be constructed in Slovenia near the city of Maribor. The reversible pumped-storage power plant Kozjak with the capacity of $2 \times 220 \mathrm{MW}$ includes an already constructed water reservoir of 3 million $\mathrm{m}^{3}$, where a steel penstock with the water column taller than $750 \mathrm{~m}$ will be erected, as shown in Figure 3. This penstock with an internal water dynamic pressure more than 100 bars and with its diameter of $4.0 \mathrm{~m}$ will be one of the strongest high-pressure penstocks in the world.

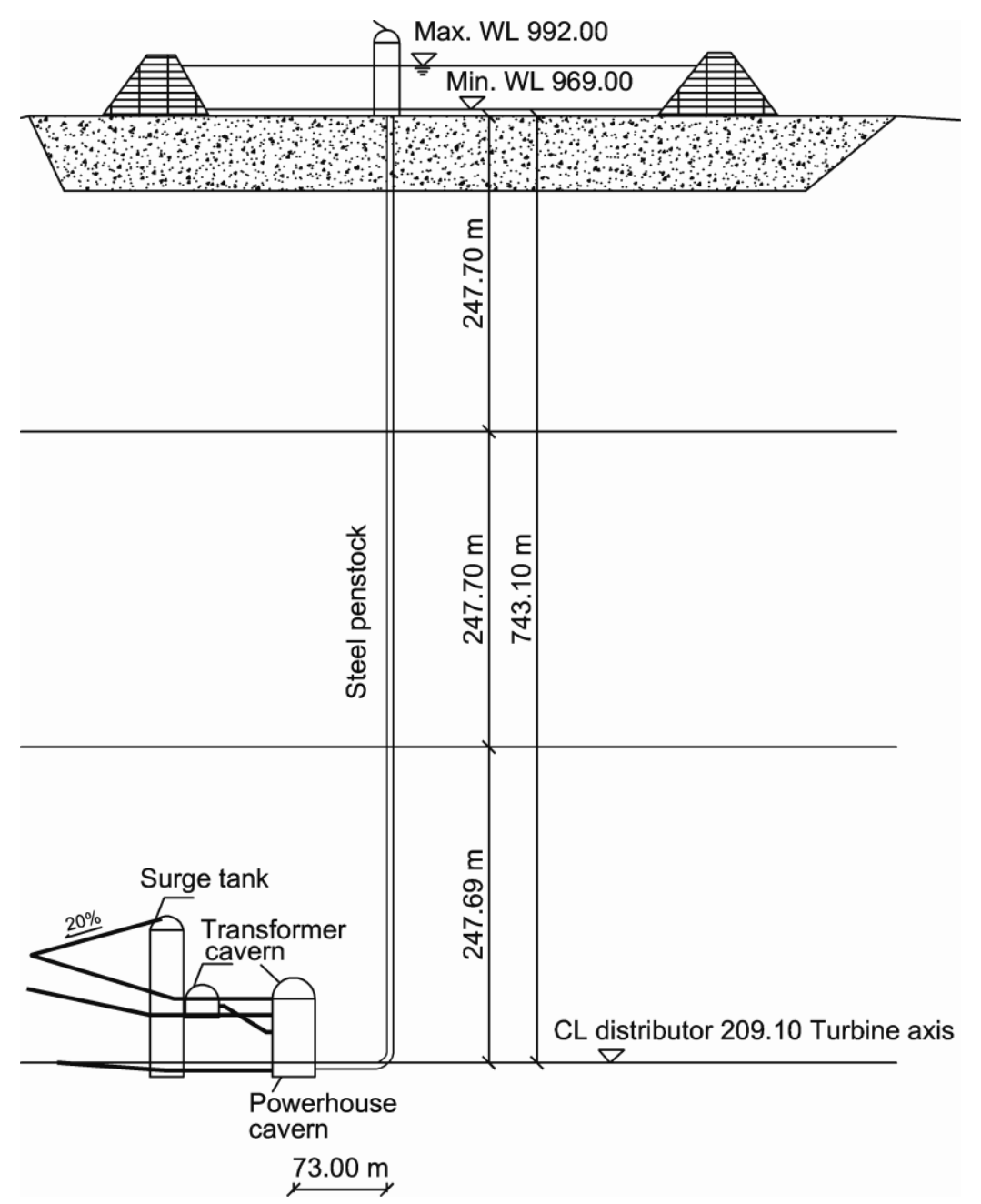

Figure 3 Vertical variant of the steel penstock Kozjak

The calculations and drawings of the reversible power plant Kozjak with a number of inclined penstock variants were made by the Slovenian company IBE Ljubljana in 2011 [18], while the vertical penstock variant was finished in 2012 [19]. The NLP optimizations of the penstock variants were then performed at the Faculty of Civil Engineering, University of Maribor [20, 21]. 
Table 1 Optimal mass of the vertical steel penstock Kozjak

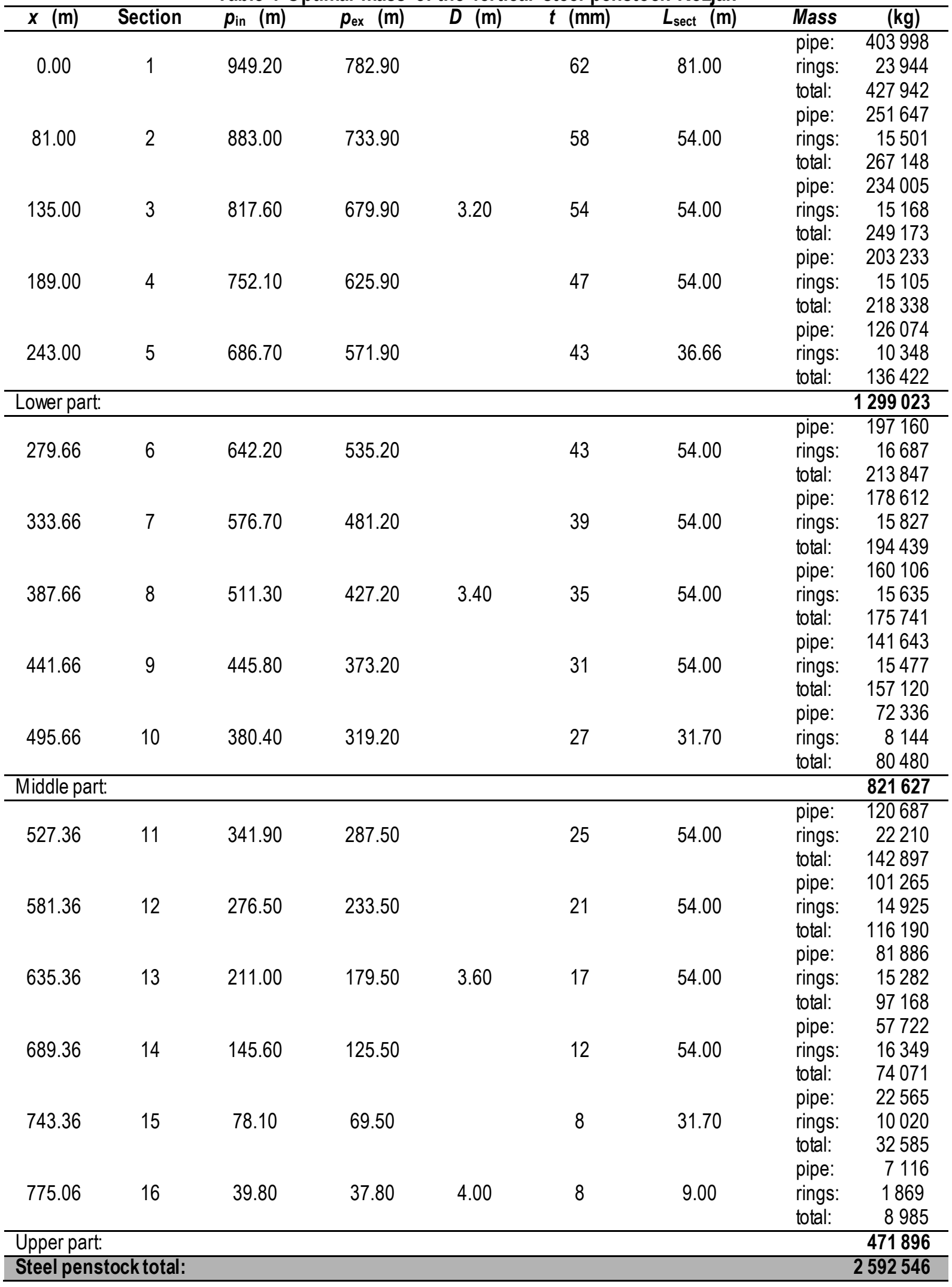

The vertical variant of the high-pressure penstock with stiffener rings is presented in this paper. The subvariant of the high-strength steel $\mathbf{S} 690$ is considered here for the entire steel structure. Sixteen different penstock Kravanja, S 
sections comprise the section lengths $L_{\text {sect }}$ (ranging from $9.00 \mathrm{~m}$ to $81.00 \mathrm{~m}$ ), the inner radii $R$ (ranging from 1.60 $\mathrm{m}$ to $2.00 \mathrm{~m}$ ), the maximal internal water pressure is $p_{i n}=94.92$ bars and the maximal external water pressure is $p_{\text {ex }}=78.29$ bars, as listed in Table 1. In addition, the input data for the optimization include the following constants: $C_{i p}=1.5, C_{e p}=1.8$, cor $=0.2 \mathrm{~cm}, \mathrm{fy}=65.0$ to $69.0 \mathrm{kN} / \mathrm{cm}^{2}, E=21000 \mathrm{kN} / \mathrm{cm}^{2}, v=0.3, \varphi=0.7, j R=j / R=0.001, \varepsilon$ $=\eta / R=0.01, u_{e}=U / e=0.2$, and $\rho=0.00785 \mathrm{~kg} / \mathrm{cm}^{3}$.

The optimization model PIPEWSROPT was applied. NLP optimization was performed using the computer program GAMS/CONOPT (the general reduced gradient method) [22]. Each penstock section was optimized separately. The total optimal mass of 2592 tons (Table 1) of steel S 690 was obtained, together with the optimal thicknesses of the pipe shell (from $8 \mathrm{~mm}$ to $62 \mathrm{~mm}$ ) and all other dimensions.

\section{CONCLUSIONS}

The paper deals with the NLP optimization of a high-pressure steel penstock with stiffener rings, for a pump storage hydropower plant. For this purpose, the NLP optimization model was developed. The defined mass objective function of the penstock's steel structure was subjected to structural constraints. The latter comprised the equations of the penstock that defined its resistance to the internal and external water pressure loads. The numerical example at the end of the paper demonstrated the NLP optimization of a large high-pressure penstock, which will be constructed in Slovenia close to the city of Maribor. The example confirms that mathematical programming optimization techniques can be usefully applied to engineering problems.

\section{Acknowledgements}

The research was supported by the National Research Programme P2-0129, grant funded by the Slovenian Research Agency, and DEM (Dravske elektrarne Maribor).

\section{References}

[1] Tapia, A.; Millan. P.; Gomez-Estern, E. 2018: Integer programming to optimize Micro-Hydro Power Plants for generic river profiles, Renewable Energy, 126, pp. 905-914, https://doi.org/10.1016/j.renene.2018.04.003

[2] Fathi-Moghadam, M.; Haghighipour, S.; Samani, H.M.V. 2013: Design-Variable Optimization of Hydropower Tunnels and Surge Tanks Using a Genetic Algorithm, Journal of Water Resources Planning and ManagementASCE, 139 (2), pp. 200-208, https://doi.org/10.1061/(ASCE)WR.1943-5452.0000243

[3] Bai, X.L.; Jia, Q.P.; Su, H.L. 2013: Optimal Design of the Stiffener Penstock Structure in a Hydropower Station, Civil engineering, architecture and sustainable infrastructure II, pts 1 and 2, Applied Mechanics and Materials, 438-439, pp. 561-564, https://doi.org/10.4028/www.scientific.net/AMM.438-439.561

[4] Wu, H.L.; Du, X.F.; Qin, S.H.; Li, Y.; Li, Q. 2012: Influence of Concrete Tension Softening Properties on the Steel-liner Reinforced Concrete Penstock, Applied Mechanics and Materials I, pts 1-3, Applied Mechanics and Materials, 275-277, pp. 1544-1548, https://doi.org/10.4028/www.scientific.net/AMM.275-277.1544

[5] Gu, H.; Yan, G.H. 2011: Analysis on Dynamic Response and its optimized design of Penstock and Expansion Joint Structure in Hydropower Station, Advanced Building Materials, pts 1-4, Advanced Materials Research, 250-253 (1-4), pp. 2892-2896, https://doi.org/10.4028/www.scientific.net/AMR.250-253.2892

[6] Haghighipour ,S.; Fathi-Moghadam, M. 2010: Optimization of hydropower conveyance systems, Journal of Food Agriculture \& Environment, 8 (2), pp. 1093-1096

[7] Anagnostopoulos, J.S.; Papantonis, D.E. 2008: Simulation and size optimization of a pumped-storage power plant for the recovery of wind-farms rejected energy, Renewable Energy, 33 (7), pp. 1685-1694, https://doi.org/10.1016/j.renene.2007.08.001

[8] Dong, W.S.; Tang, K.D.; Hou, X.M.; Liu, X.M. 2008: Research on the stability problem of hydroelectric station penstock under external pressure, 2008 International symposium on intelligent information technology application, vol II, Proceedings, pp. 508-+, IEEE Computer Soc, Los Alamitos, CA, https://doi.org/10.1109/ITA. 2008.298

[9] Li, H.W.; Ning, H.M.; Yang, Z.S. 2008: The Optimal Design Model of Steel-lined Reinforced Concrete Penstock Based on ANSYS, Proceedings of first international conference of modelling and simulation, vol Vl: Modelling and simulation in architecture, civil engineering and materials, pp. 31-35

Kravanja, S 
[10] Kravanja, S. 2014: Optimization of steel penstock in a bored tunnel, High performance and optimum design of structures and materials, 2014 International Conference on High performance and optimum design of structures and materials, HPSM/OPTI 2014, (WIT transactions on the built environment, vol. 137), pp. 337345, WIT Press, Southampton

[11] Kravanja, S. 2015: Optimization of steel liner for high-pressure penstock, Gradbeni vestnik, 64, pp. 280-286

[12] Timoshenko, S. 1940: Theory of plates and shells, $1^{\text {st }}$ edition, McGraw-Hill Book Company, New York and London

[13] Amstuz, E. 1950: Das Einbeulen von Schacht- und Stollenpanzerungen, Schweizerische Bauzeitung, 68 (9), pp. 102-105 (in German)

[14] Amstutz, E. 1953: Das Einbeulen von vorgespannten Schachtund Stollenpanzerungen, Schweizerische Bauzeitung, 71 (16), pp. 229-231 (in German)

[15] Kollbrunner, C.F.; Milosavljević, S. 1956: Beitrag zur Berechnung von auf Ausendruck beanspruchten kreiszylindrischen Rohren, Verlag Leemann, Zürich (in German)

[16] C.E.C.T., Recommendations for the design, manufacture and erection of steel penstocks of welded construction for hydro electric installations, European Committee for boilermaking and kindred steel structures, Prepared by the »Penstock« Section, 1979

[17] Brooke, A.; Kendrick, D., Meeraus, A. 1988: GAMS - A User's Guide, Scientific Press, Redwood City, CA

[18] Močnik, l.; Josipovič, Z.; Kimovec, J. 2011: Penstock dimensioning, 3. civil construction design, Penstock, Kozjak PSP, IBE Ljubljana

[19] Močnik, I. 2012: Technical Report, 3. civil construction design, 3/18 Penstock - cavern type, Kozjak PSP, IBE Ljubljana

[20] Kravanja, S. 2011: The optimization of penstock with the recommendations for the design of steel liner and the collaboration of the rock, The recommendations for the dimensioning and optimization of steel penstock, Kozjak PSP, Faculty of Civil Engineering, University of Maribor

[21] Kravanja, S. 2012: The optimization of penstock with the recommendations for the design of steel liner and the collaboration of the rock, Variant the Verical penstock, The recommendations for the dimensioning and optimization of steel penstock, ,Kozjak PSP, Faculty of Civil Engineering, University of Maribor

[22] Drudd, A.S. 1994: CONOPT - A Large-Scale GRG Code, ORSA Journal on Computing, 6 (2), pp. 207-216

Please cite this article as:

Kravanja, S.: Optimization of a steel penstock with stiffener rings, Electronic Journal of the Faculty of Civil Engineering Osijek-e-GFOS, 2018, 17, pp. 64-73, htps://doi.org/10.13167/2018.17.7

Kravanja, S 